\title{
ENHANCING EMPLOYABILITY THROUGH UNIVERSITY EDUCATION: THE ROLE OF NATIONAL UNIVERSITY COMMISSION (NUC)
}

\author{
V. C. ONYEIKE AND S. O. ONYEAGBAKO \\ (Received 9, April 2014; Revision Accepted 30, June 2014)
}

\begin{abstract}
Over $80 \%$ of graduates in Nigeria are unemployed in spite of their qualifications, they are employable yet they are not employed. The inability of the university education to meet the needs of these graduates as well as promotion of economic, self reliance and self sufficiency has resulted into youth joblessness (unemployment). These have added to increase in restiveness among Nigerian youths. This paper aims at exploring employability and focusing on the link between education and employability to determine whether employability can be enhanced through university education. The paper went further to identify some employability skills and suggested how university can be reengineered to achieve these skills for the benefit of our students and society at large through the role of National University commission (NUC).
\end{abstract}

\section{INTRODUCTION}

Education is the instrument par excellence for meeting the needs and solving the problems of society. The major role of the education industry in an economy seems to be principally that of producing the various classes of manpower needed by the economy. Thus, we have the primary, secondary and tertiary levels of education assigned respectively with differing functions as far as manpower production for the nation's economy is concerned. While the primary school level lays the foundation upon which the other levels are built, the two broad goals of secondary education are preparation of the individual for useful living within the society and also the preparation for higher education (FGN, 2004; 14-24). Tertiary education, on the other hand, is the education given after secondary education in universities, colleges of education, polytechnics and monotechnics including those institutions offering corresponding courses.
Among other roles, universities are established for the production of manpower as higher institutions of learning occupy a pivotal position in every society. The university not only receives products from preceding tiers, it is usually the final destination for formal teaching and learning before the ultimate launch into the world of employment or entrepreneurship. UNESCO (1998) in Bassey and Bassey (2011) explains that higher institutions of learning, as role models of innovation and change at large, are expected to play a critical role in promoting sustainable economic, social and cultural development. This implies that institutions of learning are at the forefront of contributing positively and powerfully to the society.

University is one of the tertiary institutions existing in most countries of the world for specific purposes. In Nigerian, universities exist to pursue some primary and secondary mandates. The primary mandate is to train people for acquisition of the degrees while the provision of community services remains the

V. C. Onyeike, Department of Educational Management, Faculty of Education, University of Port Harcourt, Port Harcourt, Nigeria.

S. O. Onyeagbako, Department of Life Science Education, Faculty of Education, Imo State University, Imo State, Nigeria. 
secondary mandate. For any nation to be economically buoyant, politically stable and culturally appreciable and marketable, the university has uncompromising responsibility of producing skilled graduates for the country for productive vibrancy in all areas of economic endeavours.

However, available literature on the management of education in Nigeria is filled with the fact that Nigerian education has fallen short of expectations - it has failed to produce the type of skilled manpower who are employable, productive, and self-reliant (Babalola, 2007). Students are trained predominantly under theoretical teaching - learning situations even in those courses that require specialized equipment, workshops and tools. The school system in Nigeria is characterized by large class size, inadequate qualified teachers, few instructional aids, old and dilapidated school buildings with leaking roofs, insufficient classroom and staff offices, ill-equipped science laboratories, poorly equipped engineering workshops, inadequate staff development, examination malpractice and unmotivated work force (Hartnett, 2000). That may seem why this dismal picture of the school system in Nigeria is partially held responsible for lack of required appropriate skills and hence the high unemployment rate amongst graduates.

University Education is expected to provide certain traits on the beneficiaries which among other things will enable them to perform certain task independently. These traits confer on them certain degree of confidence and independence.

Employability is about being capable of getting and keeping fulfilling work. According to Harvey (2000) graduates need to be more pliable to the growing number of career changes experienced through life, because of the increase in short term contracts, part-time work, outsourcing and home-working. Employment and employability is not the same thing. Being employed means having a job whereas being employable means having the attributes needed to maintain employment and progress in the workplace. With globalization taking place and the employment equity act of 1998 in force the job market has become rather competitive. Now a person not only has to compete for a job with the different people from his own community or country but also with the people who emigrate from other countries.
Hence, the purpose of this paper is to explore employability and focus on the link between education and employability to determine whether employability can be increased or enhanced through NUC role in higher education.

\section{LITERATURE REVIEW}

In spite of widespread assumptions that employability is a concept of the current period, scholars of employability such as Peter Knight and Mantz Yorke note that the notion did not simply emerge as a way of explaining necessary responses to a radically changed economic and public policy environment since 1990.

Gazier (1998), one of the leading theorists of employability, maintains that the concept has gone through seven stages over the past century.

- Dichotomic Employability: This approach emerged in the beginning of the $20^{\text {th }}$ century in Britain and America. It made a distinction between those that are/can be employed and those that cannot be. This is a form of reformation of the longstanding Anglosaxon dichotomy between the "deserving poor" (hard working and morally upright individuals who have fallen on hard time due to misfortune - e.g, illness or widowhood) and the "undeserving poor" (those who are lazy and morally degenerate). The former deserve charity, the later must be reformed.

- $\quad$ Socio-Medical Employability: This theme emerged around the time of world war two in the USA, Britain and Germany in particular. It focused particularly on the social, physical or mental deficits of individuals that made them unfit for employment.

- Manpower policy employability: This account developed mainly in the USA in the 1960s, and extended the deficit approach of the socio-medical model to other societal groups. Again, the focus was on the gap between their knowledge, skills and attitudes and those required by the labour market.

- $\quad$ Flow employability: This is a primary French account, which emerged in the 1960s. it was radically different from the earlier approaches in focusing primarily on the demand side and the accessibility of employment within local and national economies, with employability defined as "the objective expectation, or more or less high probability, that a person looking for a job can have of finding ones" (Gazier 1998). 
- Labour market performance

employability: This emerged internationally towards the end of the 1970s. This concept focuses on the measurable labour market outcomes that result from specific policy interventions. These measures typically include period employed, hours worked and wage rates.

- Initiative employability: This account coalesced in the late 1980s in the North American and European resource development literature, which was starting to discuss the notion of the end of the "Salaryman" who worked for the same large corporation (or state bureaucracy) from leaving school until recruitment. With the purported end of a job for life, this account argued that successful career development now required the development of skills and attitudes that could make workers both succeed in their current jobs and motivated to get a better job in another organization. The stress here is firmly on the individual's initiative and agency.

- Interactive employability: Following on swiftly from this account, emerged the notion of interactive employability. Whilst accepting the importance of individual agency, this account sought to balance this with a development of some of the insights of the French flow employability school regarding structural factors. Thus, it was argued that the employability of the individual is partly relative to the employability of others in the labour market, both as competitors but also in the sense that high levels of dispersed employability might attract new employment opportunities to an area. The state of demand locally and nationally is also considered, as are the rules and institutions that govern the labour market, reflecting the rise of institutional economics at this record. Thus, this account implicates employers and policymakers in the employability challenge alongside individuals.

\section{THE CONCEPT OF EMPLOYABILITY}

A report carried out by Hillage and Pollard (1998) for the Department for Education and Skills (DFES) University of Birmingham found that Employability is about having the ability to acquire initial employment, keeping employment and acquire new employment if required. For an individual, employability depends upon:

i. Assets in terms of knowledge, skills and attitudes

ii. The way these assets are used and deployed, iii. Presentation of assets to potential employers

iv. The context within which the individual works, e.g. labour market, personal circumstances.

Comprehensively, employability is the capability to move self-sufficiently within the labour market to realize potential through sustainable employment. It is about being capable of getting and keeping fulfilling work. Employability is a difficult concept to define. Fugate (2004) and Little (2001) agree that employability is a multi-dimensional concept and factors relevant to obtaining a job and factors relevant to the preparation for work need to be distinguished between.

Yorke (2004) defined employability as a set of achievements-skills, understanding and personal attributes-that make graduates more likely to gain employment and be successful in their chosen occupations, which benefit themselves, the workforce, the community and the economy. Employability is not the same as gaining a graduate job, rather it implies something about the capacity of the graduate to function in a job and be able to move between jobs, thus remaining employable throughout their life.

From an employer's perspective, employability is the capability of a graduate to display attributes that employers predict will be necessary for the effective functioning of their organization in the future (Harvey, 1997). Graduates need to be more pliable to the growing number of career changes experienced through life, because of the increase in short term contracts, part-time work, outsourcing and homeworking (Harvey, 2000a). Employment and employability are not the same thing. Being employed means having a job, whereas being employable means having the attributes needed to maintain employment and progress in the workplace. Employability from the view of higher education institutes is therefore about producing graduates who are capable and able, and these impacts upon all areas of university life, in terms of the delivery of academic programmes and extra curricula activities.

\section{Employability Skills}

The concern of employers today are finding good workers and training them. According to Robinson (2000), employability skills are those basic skills necessary for getting, keeping and doing well on a job. These are the 
skills, attitudes and actions that enable workers to get along with their fellow workers and supervisors and to make sound, critical decisions. Unlike occupational or technical skills, employability skills are generic in nature rather than job specific and cut across all industry types, business sizes, and job levels from the entrylevel worker to the senior-most position. Robinson also discusses that in order for one to become a valuable employee, an individual needs to think critically, act logically, be able to evaluate situations to make decisions, and to solve problems.

Finding from Dearing (1997) showed key skills to consist of four components: learning how to learn, Information technology (IT), Numeracy, and communication. He suggested that it was important that these were developed at undergraduate level. The Department for Education and skills (DFES) University of Birmingham adds teamwork and problem solving to this list. There are many different lists of key skills, although there is general agreement about the importance of communication, numeracy, teamwork, Information technology (IT) and problem solving (Dunne, 2000). These are considered to be generic skills as they represent skills that can be used to support study in any discipline. The possession of some key skills Information technology (IT), numeracy for example, will facilitate the acquisition of subject understanding (Yorke, 2001), as using IT for research will enable students to learn more about their discipline.

Employability skills are defined by Coopers and Lybrand (1998) in term of four key areas:

i. Key skills - communication, Information technology (IT), etc

ii. Traditional intellectual skills e.g. critical evaluation, logical argument

iii. Knowledge of organizations and how they work; and

iv. Personal attributes - motivation, selfreliance

Whereas Robinson (2000) defines employability skills into three general categories

i. Basic academic skills - e.g. reading, writing, arithmetic

ii. Higher order thinking e.g. reasoning, thinking, creatively and

iii. Personal qualities - e.g. self-control, team spirit

The critical employability skills vary considerably in the way in which they are organized but most researchers agree on the same skills and traits required by employers. Employability skills are not merely attributes that employers desire in prospective employees, rather, many employers now require applicants to have these skills in order to be seriously considered for employment. Following then review of over 100 studies undertaken to identify the characteristics and skills desired by contemporary employers, Sherer and Eadie state, "it is very important... that the schools provide the basic employability skills so that all students and adults are equipped to handle the complexities of their jobs throughout their lives" (1997: 16).

Within the university education, the generic skills needed to enhance graduate employability whether defined in terms of immediate work-readiness or longer term career prospect are: literacy, problem solving skills, team-working skills, and understanding of the world of work which refers to knowledge about the ways in which organizations work, what their objectives are and how people in the organization do their jobs (Coopers and Lybrand, 1998).

\section{Measuring Employability}

An Employability Performance Indicator (EPI) is thought by many to be too crude and that it could be used inappropriately (Harvey, 2000b). An EPI will probably be used as a management tool for the allocation of finding against performance criteria and also to produce information to inform students about potential career routes that might follow a particular university course (Smith, 2001). Concern has also been expressed that an EPI backed by the Treasury would be primarily economically-driven, rather than related to the education mission of HEls and the broader purpose of higher education.

\section{There are two main purposes of EPI:}

i. Accountability and improvement, accountability through benchmarking and league tables, accompanying press coverage and through additional student numbers, and

ii. Improvement through internal institutional development and continuous quality improvement

Harvey (2000b), states that an EPI must have greater emphasis on improvement than on accountability, but that any EPI must be seen as part of the development of the learning process, 
not detached from it, Harvey (2001) concludes that any evaluation of employability needs to clearly indicate areas for internal improvement, rather than simply ranking institutions. There is a danger that institutions will focus too much on their place in the league tables as they seek to improve their scores. This may be at the expense of fulfilling the educational aims that students should leave with a rich variety of employment orientated skills, understanding and attributes (Knight and Yorke, 2001).

The Roles of National
Commission
Employability

The National Universities Commission (NUC) as a national body established in 1962 and charged with the responsibilities of granting approval for all academic programmes run in Nigerian universities, granting approval for the establishment of all higher educational institutions offering degree programmes in Nigeria, ensuring quality assurance of all academic programmes offered in Nigerian universities; and standardization of educational programmes in the universities in line with the policy thrust that quality assurance focuses on education for competence. To ensure that these functions are met, NUC should ensure an orderly development of university education in Nigeria, to maintain its high standard, and to ensure its adequate funding. The NUC should ensure that the following are being done.

i. Motivation of qualified lecturers: The NUC in collaboration with the university governing council should ensure that more competent and qualified lecturers are recruited and well motivated to lecture, especially where they are needed. It is worthy to note that provision of staff development and welfare programmes such as regular payment of new salaries, improved authority-staff relationship, regular promotion, in-service training, loan facilities, well furnished staff quarters and conducive office accommodation as well as provision of appropriate education facilities complements and promote system efficiency which in turn increase quality of the output.

ii. Curriculum Review: The NUC should ensure that there is periodic review of curriculum. The periodic curriculum review should incorporate the quantitative and qualitative yearnings and aspirations of the society from time to time because society prescribes the goals that education follows (Fafunwa, 2004). The curriculum content should be more responsive to the needs of the society in order to make it relevant, effective and efficient

iii. Regular and Effective University Accreditation: The NUC should ensure that universities are genuinely and regularly accredited and certified to ensure the maintenance and sustenance of high standard. Accreditation exercise should now extend to accreditation and certification of physical facilities (buildings, offices, libraries and laboratories) and approval of university faculty programmes. The NUC should also introduce a measure of university performance that captures graduate labour market performance in the accreditation of department.

iv. Provision of Adequate Educational Facilities: The NUC should ensure that educational facilities such as contemporary textbooks, mass media gadgets, computers, well stocked libraries and laboratories, workshops, etc are adequately provided in every university. The quality of output produced in the university cannot be stronger than teaching and research environment provided in the system hence NUC in collaboration with government and major stakeholder should intensify their efforts towards the provision of educational facilities.

v. Improved Funding: The NUC in collaboration with ASSU should ensure that fund allocation to education is geared towards $26 \%$ of UNESCO recommendation. Obviously, failure to respect and maintain this recommendation is a present and clear danger to achievement of quality higher education in the country.

$\mathrm{Vi} \quad$ Establishing a Workable link between Universities and Employers of Labour: This will enable it to be acquainted with those programmes that are selling in the job market and required by employers of labour.

\section{Educational Acquisition and Employability}

For business, the employee's intellectual ability can be treated as an asset. This asset can be used to create products and services which can then be sold. The more highly-educated workers available, the more a firm can theoretically produce. The knowledge and skills of workers available in the labour supply is a key factor determining both business and economic growth. Economies with a significant supply of skilled labour, brought on through school education as well as training, are often able to capitalize on this through the development of 
more value-added industries, such as high-tech manufacturing.

According to Lees, there is lack of a common language of skills between higher education institutions and employers (Dunne, 2000). Part of the problem with the skills agenda and initiatives in higher education is the assumption that skills has the same meaning in the education context as the employment context (Holmes, 2001). This is not necessarily true. The relationship between the employabilitydevelopment opportunities provided by the higher education institute and the employment of graduate is complicated by the role played by employers who convert employability into graduate employment (Harvey, 2001).

Increasingly, graduate attributes are more important than the degree or subject studied (Harvey, 2000). For some employers, the degree or subject studied is not as important as the graduate ability to handle complex information and communicate it effectively (Knight, and Yorke, 2000). Graduate recruiters want a variety of other skills, personal and intellectual attributes, rather than specialist subject knowledge. Oral communication, teamwork, self-management, problem solving, leadership (warn and Tranter, 2001). Employability skills are all important. Employers increasingly want graduates who have selftheories that are marked by confidence, optimism, and a belief that they can make a difference. Employers want graduates who can adapt to the workplace culture, who can use their abilities and skills to evolve the organization and who can participate in innovative teamwork (Little, 2001). Employers also value critical thinking (reflection) as this is required for innovation and participating leading change. Morley (2001) suggests that the concept of employability needs to be developed to balance out the power-relations embedded in the employability discourse of recruitment and retention. She implies that the education process should also encompass employers so that they are more sensitive towards issues of difference such as race, class, gender, sexual orientation and disability.

\section{CONCLUSION}

Education at a glance, published by the Organization for Economic Cooperation and Development (OECD), which covers research done over 34 countries, have included in their current edition (Education at a glance 2011) a special indicator looking at how educational attainment affects participation in the labour market. The findings highlight the strong link between tertiary educations and employability, particularly in the economic downturns of recent years. The following were noted: In all OECD countries, individuals with tertiary-level degree have a greater chance of being employed than those without such a degree.

Education is generally good insurance against unemployment and for staying employed in difficult economic times. In 2009 average unemployment rates across OECD countries stood at $4.4 \%$ for those with a tertiary education, $68 \%$ for those with an upper secondary education, and $11.5 \%$ for those who have not attained an upper secondary education (Education at a glance, 2011).

While possessing a tertiary degree is a strong positive factor in employability, it is not guarantee of employment. Good education and skills are essential, especially in the current economic climate. Although higher education institutes provide individuals with a better chance of being employed, they need to focus more on employability skills required by individuals once they graduate.

\section{REFERENCES}

Babalola, J. B., 2007. University Autonomy and financial reforms in Nigeria. Historical background, issues and recommendation from experience. In S.B. Babalola and B. O. Emenemu (eds) Issues in higher education: Research evidence from subsahara Africa. Lagos: Bolabay Publication.

Bassey, S. U and Bassey, U. U., 2011. Management of Higher Education in Africa. Uyo: Abaam Publishing Co.

Coopers, M and Lybrand, D., 1998. Skill development in Higher Education. (London, Committee of Vice Chancellors and Principals/ Department for Education and Employment)

Dearing, R., 1997. Higher Education in the learning society. Report of the National Committee of Inquiry into Higher education. HMSO, Norwich. 
Dunne, E., 2000. Bridging the gap between industry and higher Education: training academics to promote student teamwork. Innovation in Education and Training international, 37, (4): 361-371.

Federal Republic of Nigeria., 2004. National Policy on Education. Lagos: NERDC

Field, J., 2000. Skills and employability in the limelight, exploring the public presentation of the New Deal. Research in post compulsory Education 5, (3): 255271.

Fugate. M., 2004. Employability: A psycho-social contract, its dimensions, and applications. Journal of Vocational Behaviour (65):14-38.

Gazier, B., 1998. Employability: definitions and treads. In Gazier, B. (ed) Employability: Concepts and policies. European Employability observatory, Berlin.

Harvey, L., 1997. Graduates work: Organizational Change and Student attributes. Centre for Research into Quality, University of Birmingham.

Harvey, L., 2000a. New realities: The relationship between higher education and employment. Tertiary Education and Management 6, 3-17

Harvey, L., 2000b. An employability performance indicator. Tertiary Education and Management Perspectives 6, 20-26.

Harvey, L., 2001. Defining and measuring employability. Quality in higher education, 7, (2): 97-109.

Hartnett, C., 2000. Employability and Enterprise: Evidence from the North East. Urban Studies 42, (2): 271-83.

Hillage, J and Polland, E., 1998. Employability: developing a framework for policy analysis. Research Brief 85, Department for Education and Employment.

Holines, L., 2001. Reconsidering Graduate Employability: the graduate identity approach. Quality in Higher Education 7, (2): 111-119.

Knight, $\mathrm{P}$ and Yorke, M., 2001. Employability through the curriculum, Skills plus project.

Little, B., 2001. Reading between the lines of graduate employment. Quality in higher education $7,(2)$ : 121-129.

Morlley, L., 2001. Producing New Workers: quality, equality and employability in higher education. Quality in higher education 7, (2): 131-138.

OECD., 2011. Education at a Glance 2011: OECD publishing http://dxidoi.org/10.1787/ea8-2011-en.

Robinson, J. P., 2000. What are employability skills? The workplace 3(3) 1-3 September 2000 (ACES,2000).

Smith, J., 2001. Graduate Employability: Policy and Performance in Higher Education in the UK. The Economic Journal 110, (1): 382-411.

Warn, J and Tranter, P., 2001. Measuring quality in higher education a compulsory approach. Quality in Higher Education, 7, (3): 191-198.

Yorke, M., 2001. Employability in the first cycle higher education. A working paper for the skills plus. Project Liverpool John Moores University.

Yorke, M., 2004. Employability in Higher Education: what it is - what it is not, Higher Education www.employability.ed.ac.uk/what/ 